\title{
Microstructure of Aluminium Alloys Casting Intended for Cyclical Thermal Stress
}

\section{Iva Nova, Jiri Machuta}

Faculty of Mechanical Engineering, Technical university of Liberec, 46117 Liberec, Czech Republic. E-mail: iva.nova@tul.cz,jiri.machuta@tul.cz

The article presents the microstructure and mechanical properties of aluminium cylinder head engine. The cylinder heads are manufactured by gravity casting. Gravity casting (GC) is very good process for making complex mechanical parts of light metal like aluminium alloys. However recently another light metal has come to the forefront in the quest for fighter vehicles and improved fuel economy. The most commonly used aluminium alloy for gravity casting automotive components is the Al-Si-Mg type. AlSi10Mg is a good purity of aluminium alloy with good corrosion resistance, very good mechanical properties and good castability. AlSi10Mg alloy is slightly hypoeutectic with a low content of accompanying elements and impurities. Exhibits excellent casting and technological properties (good machinability and corrosion resistance). During solidification of this alloy is formed a shrinkage, which is necessary to eliminate by risering. This alloy has a wide foundry application, it is used for gravity casting into metal moulds for production of cylinder heads. This alloy is used for precipitation hardening intermediate Mg2Si phase. It was cast a cylinder head of AISi10MgMn alloy and it was monitored the structure of the casting.

Keywords: aluminium alloy, crystallization, microstructure, cylinder head engine.

\section{Acknowledgement}

The project is financially supported by SGS 21122.

\section{References}

[1] MICHNA, Š., et al. (2005). Encyklopedie hliníku. (encyclopedia of aluminum). Prešov: Adin, 2005.701 p. ISBN 80-89041-88-4 (in Czech).

[2] VOJTĚCH, D. (2006). Kovové materiály. 1. vyd. Vysoká škola chemicko- technologická v Praze. Praha, 185 s. ISBN 80-7080-600-1.

[3] PÍŠEK, F. (1973). Nauka o materiálu I: Nauka o kovech. 3. svazek. Neželezné kovy. (Material Science I: Theory of metals. The third volume. Non-ferrous metals). 2. přepracované vydání. Praha: Academia, 595 p, (in Czech).

[4] CAMPBELL, J. (2004). Casting practise, The 10 rules of casting. First publication. Elsevier Science Ltd. ISBN 0750647914.

[5] CAMPBELL, J. (2003). Castings, The new metalurgy of casting metals. Second publication. Elsevier Science Ltd. ISBN 0750647906.

[6] SULAIMAN, S., HAMOUDA, A. (2004). Modelling and experimental investigation of solidification process in sand casting. Journal of Materials Processing Technology 155-156 (2004) 1723-1726.

[7] TAYLOR, J.A. (2004). The effect of iron in Al-Si casting alloys. In 35th Australian Foundry Institute National Conference, p. 148-157.

[8] CAO, X., CAMPBELL, J. (2006). Morphology of Al5FeSi Phase in Al-Si cast alloys. MaterialsTransactions. 47(5), 1303-1312.

[9] MACKAY, R.I. (1996). Quantification of Iron in Al-Si Foundry Alloys via Thermal Analysis. Master thesis, McGill University, Montreal, Canada.

[10] TAYLOR, J.A. (2012). Iron-containing intermetallic phases in Al-Si based casting alloys. Procedia Materials Science 1, 19- 33. DOI: 10.1016/j.mspro. 2012.06.004

[11] KUMARI, S.S., PILLAI, R.M., RAJAN, T.P., PAI, B.C. (2007). Effects of individual and combined additions of $\mathrm{Be}, \mathrm{Mn}, \mathrm{Ca}$ and $\mathrm{Sr}$ on the solidification behaviour, structure and mechanical properties of $\mathrm{Al}-7 \mathrm{Si}-0.3 \mathrm{Mg}-0.8 \mathrm{Fe}$ alloy. Materials Science and Engineering A. 567-573. DOI: 10.1016/j.msea.2007.01.082.

[12] TILlOVÁ, E., CHALUPOVÁ, M. (2009). Structural analysis of AlSi cast alloys. Žilina: EDIS.

[13] HURTALOVÁ, L., TILlOVÁ, E. (2013). Elimination of the negative effect of Fe-rich intermetallic phases in secondary (recycled) aluminium cast alloy. Manufacturing Technology. 13(1), 44- 50. 
[14] BOLIBRUCHOVÁ, D., ŽIHALOVÁ, M. (2013). Possibilities of iron elimination in aluminium alloys by vanadium. Manufacturing Technology. 13(3), 289-296.

[15] MACHUTA, J., NOVÁ, I. (2015). Simulation calculations of solidification and cooling of copper alloys casts. Manufacturing Technology Vol. 15 No 4. pp. 591-596.

[16] BOLIBRUCHOVÁ, D., TILLOVÁ, E. (2005). Zlievarenské zliatiny Al-Si. (Casting alloys Al-Si). Žiliňská univerzita v Žilině, 180 s. ISBN 80-8070-485-6. (in Slovak).

[17] BAŘINOVÁ, D., EXNER, J. (2003). Evaluation of simulation casting cylinder head of AlSiloMg alloy (Industry research report).

[18] Database of software Magma 5.1 belonging to the company MAGMA GmbH, Germany.

\section{Paper number: M2016200}

Copyright (C) 2016. Published by Manufacturing Technology. All rights reserved. 